MARTA WIRASZKA ${ }^{1}$

Instytut Historii Sztuki

Uniwersytet Kard. Stefana Wyszyńskiego w Warszawie

ORCID: 0000-0002-8634-2380

\title{
KAPLICA BORZEWSKICH NA CMENTARZU W OBORACH. PRZYKLAD BUDOWLI GROBOWEJ INSPIROWANEJ TWÓRCZOŚCIĄ FRIEDRICHA AUGUSTA STÜLERA
}

\section{The Borzewski family chapel at the cemetery in Obory. An example of a tomb building inspired by the works of Friedrich August Stüler}

\section{Abstract}

The subject of the analysis is the grave chapel of the Borzewski family, which was erected in 1863 at the cemetery in Obory (Kuyavian-Pomeranian Voivodeship, Golub-Dobrzyń county, Zbójno commune), by the then heir of Ugoszcz, Zdzisław Borzewski. The architecture of the building, the designer of which is unknown, shows resemblance to contemporary projects of leading Berlin architects of the mid-nineteenth century. Its façade is a replica of the porch of the Lutheran Church of St. John the Baptist in the Berlin district of Moabit (F.A. Stüler, 1851-1857), and the window frames in the side elevations are deceptively similar to the architectural setting of the main entrance of the building at Victoriastraße 6 in Berlin (G.F. Hitzig, 1855-1859).

Keywords: Obory, Borzewski family chapel, Neo-Renaissance, Neo-Romanism, Friedrich August Stüler

\section{Streszczenie}

Przedmiotem analizy jest kaplica grobowa Borzewskich, którą wzniósł w 1863 r. na cmentarzu w Oborach (woj. kujawsko-pomorskie, pow. golubsko-dobrzyński, gm. Zbójno) ówczesny dziedzic Ugoszcza, Zdzisław Borzewski. Architektura budowli, której projektant jest nieznany, wykazuje związki ze współczesnymi realizacjami czołowych berlińskich architektów połowy XIX w. Jej fasada stanowi powtórzenie kruchty kościoła luterańskiego św. Jana Chrzciciela w berlińskiej dzielnicy Moabit (F.A. Stüler, 1851-1857), a obramienia

\footnotetext{
1 Dr Marta Wiraszka - wykładowca historii architektury w Instytucie Historii Sztuki UKSW w Warszawie. Zajmuje się zagadnieniami z historii urbanistyki i architektury XIX i pierwszej połowy XX w., w szczególności byłych kresów południowo-wschodnich Rzeczypospolitej oraz kaplic i mauzoleów budowanych na polskich cmentarzach wyznań chrześcijańskich. E-mail: m.wiraszka@uksw.edu.pl.
} 
okien w elewacjach bocznych są łudząco podobne do oprawy architektonicznej głównego wejścia do budynku przy Victoriastraße 6 w Berlinie (G.F. Hitzig, 1855-1859).

Słowa kluczowe: Obory, kaplica Borzewskich, neorenesans, neoromanizm, Friedrich August Stüler

$\mathrm{K}$ aplica grobowa rodziny Borzewskich znajduje się we wsi Obory w województwie kujawsko-pomorskim (pow. golubsko-dobrzyński, gm. Zbójno). Została zbudowana na cmentarzu katolickim założonym w drugiej połowie XVIII w. przy kaplicy św. Krzyża (1686), w miejscu pierwszej lokacji klasztoru oo. karmelitów trzewiczkowych. Nekropolia, najstarsza z zachowanych na Ziemi Dobrzyńskiej, zajmuje płaską część wzniesienia zwanego w XVII w. „Grodziskiem”, później „Kalwarią”2. Kaplicę ufundował w 1863 r. Zdzisław Borzewski, właściciel pobliskiego majątku ziemskiego i pałacu w Ugoszczu³. Zamiar wzniesienia budowli grobowej pw. św. Antoniego zrodził się po śmierci ojca fundatora, Antoniego Grzegorza Feliksa Borzewskiego, który zmarł 11 lipca 1860 r. ${ }^{4}$ Tak jak większość przedstawicieli tamtejszego ziemiaństwa został on pochowany, jak napisano w nekrologu, we „wspólnym grobowcu okolicy naszej” - w klasztorze oo. karmelitów w Oborach ${ }^{5}$. Od tej tradycji odszedł jego syn, który dla siebie i najbliższej rodziny postanowił wznieć oddzielne lokum na cmentarzu. Pierwszą osobą pochowaną w nowym miejscu była żona Zdzisława, Maria z Szydłowskich Borzewska (zm. 27 VIII 1868).

Borzewscy herbu Lubicz pochodzili z Mazowsza, z okolic Płocka $(\rightarrow$ wieś Borzewo Wielkie). Nazwisko to występuje w źródłach od XV w. Na Ziemię Dobrzyńską przenieśli się w końcu XVIII w. W 1790 r. właścicielem Ugoszcza został Ludwik Borzewski (1755-1807), który odkupił majątek od Aleksandra Zielińskiego. Po nim dobra przeszły na starszego syna Antoniego Grzegorza Feliksa (1796-1860), który przekazał go w spadku synowi, Zdzisławowi (1833-1884) - przyszłemu fundatorowi kaplicy w Oborach. Po śmierci Zdzisława dzieci z pierwszego małżeństwa z Marią Szydłowską (1844-1868) - Julia Maria Antonina (1866-1924; zamężna ze Stefanem hrabią Sumińskim) i Antoni (1868-1920; żonaty z Heleną

\footnotetext{
2 Pierwotna nazwa wzniesienia pochodziła zapewne od grodu wczesnośredniowiecznego, który dawniej zajmował szczyt wzgórza. Określenie „Kalwaria” pojawiło się dopiero w XVIII w. po wzniesieniu kaplicy św. Krzyża w 1746 r. (w miejsce wcześniejszej z 1686 r.), z którą związane były nabożeństwa Drogi Krzyżowej. Cmentarz przeszedł gruntowną metamorfozę w latach 1846-1848. Zyskał wówczas szerokie schody z kamienia polnego i dwie katakumby przy murze ogrodzeniowym (południową - dwukondygnacyjną i zachodnią - trójkondygnacyjną). Kaplicę św. Krzyża przebudowano, cały zaś teren splantowano i nasadzono nowe drzewa. Nieco później ukończono otaczanie cmentarza ceglanym murem oraz zbudowano bramę cmentarną. Zob. Katalog Zabytków Sztuki w Polsce (dalej: KZSP), t. 11: Woj. bydgoskie, z. 9 pow. lipnowski, opr. R. Brykowski, I. Galicka, H. Sygietyńska, Warszawa 1969, s. 44-45; M. Krajewski, A. Mietz, Zabytki ziemi dobrzyńskiej. Przewodnik biograficzny, Włocławek 1996, s. 102-104.

3 Szczegółowe informacje na temat pałacu w Ugoszczu zamieszcza Romualda Hankowska. Zob. R. Hankowska, Ugoszcz - pałac, w: Materiały do dziejów rezydencji w Polsce. Ziemia Dobrzyńska, t. 2, cz. 1, red. S. Kunikowski, Włocławek 2002, s. 161-190 (tamże omówiona wcześniejsza literatura, s. 162-165).

4 Nekrolog i akt zgonu: K.J., (Art. nad.) Z Lipnowskiego dn. 15go lipca, „Kurier Warszawski”, 1860, nr 220, s. 1246; Archiwum Państwowe w Bydgoszczy (dalej: APB), Akt zgonu Antoniego Borzewskiego, par. Ruże, Ugoszcz, 1860, nr 31.

5 Cyt. za: K.J., (Art. nad.)..., dz. cyt., s. 1246.

6 Nekrolog Marii z Szydłowskich Borzewskiej, „Dziennik Poznański”, 1868, nr 199, b.s. (z dn. 30 VIII).
} 
Konstancją Grotowską) odziedziczyły dobra Ugoszcz. Pozostałej czwórce z drugiego małżeństwa z Zofią Kożuchowską: Stefanowi (1874-1904), Arturowi (1876-1938), Zdzisławowi (1878-1901) i Jadwidze (1880-?) przypadły dobra Młodzieszyn w powiecie sochaczewskim. Ostatnimi właścicielkami majątku w Ugoszczu były wdowa po Antonim, Helena Konstancja Borzewska (1860-1939), i adoptowana przez nią siostrzenica jej męża, Helena Sumińska (zm. 27 XI 1943)7. Borzewscy należeli do średniozamożnej szlachty herbowej, która czerpała swoje dochody z ziemi, a od 1900 r. również z udziałów w cukrowni Ostrowite, odkąd Antoni Borzewski został jej współzałożycielem ${ }^{8}$.

Dotychczasowa wiedza na temat zabytku sprowadza się do znajomości podstawowej faktografii, którą zebrał i opublikował w 1866 i 1869 r. ks. Maciej Zagłoba Smoleński. Dzięki jego skrupulatności znane są informacje dotyczące fundatora i roku budowy kaplicy9. Wiek później budowla grobowa Borzewskich doczekała się pełniejszego opisu w Katalogu Zabytków Sztuki, opracowanego przez Ryszarda Brykowskiego, Irenę Galicką i Hannę Sygietyńską ${ }^{10}$. Następne publikacje, w których jest wzmiankowana, będą tylko powtarzały wcześniejsze ustalenia ${ }^{11}$.

Autorzy Katalogu w opisie kaplicy zaznaczyli, że jest ona: „Murowana z cegły, otynkowana. Prostokątna, poprzedzona wgłębnym portykiem z parą kolumn. Wewnątrz strop. Fasada zwieńczona niskim trójkątnym przyczółkiem. [Nad nią - M.W.] dach siodłowy, kryty blachą. W portyku na kolumienkach rzeźby kamienne aniołków, wyobrażające rodzeństwo Engelströmów: Zygmunta Rafała (zm. 1854) i Gustawa Adolfa (zm. 1857). [Wewnątrz M.W.] płyta nagrobna Heleny Borzewskiej (zm. 1848), z czarnego marmuru, inskrypcyjna" ${ }^{\prime 2}$. Pominęli natomiast tablicę z białego marmuru umieszczoną na zewnątrz budowli na

\footnotetext{
Archiwum Państwowe w Toruniu oddział we Włocławku (dalej: APT oddz. we Włocławku), Akt urodzenia Ludwika Borzewskiego, par. Kikół, 1758 (17 X 1858); APT oddz. we Włocławku, Akt ślubu Ludwika Borzewskiego i Salomei Nałęcz, par. Kikół, 1796 (2 II 1796); Archiwum Archidiecezjalne we Włocławku, Akt urodzenia Antoniego Grzegorza Feliksa Borzewskiego, par. Czernikowo, 1796, nr 3972; APT oddz. we Włocławku, Akt urodzenia Zdzisława Gabriela Ludwika Stanisława Zygmunta Borzewskiego, par. Ruże, 1833, nr 44; APT oddz. we Włocławku, Akt Zgonu Salomei z Nałęczów Borzewskiej, par. Ruże, Gizinek, 1833, nr 18; Nekrolog Zdzisława Borzewskiego, „Kurier Warszawski”, 1884, nr 189a, s. 3, nr 191a, s. 1; Nekrolog Zdzisława Borzewskiego (syna Zdzisława i Zofii z Kożuchowskich), „Kurier Warszawski”, 1901, nr 130, s. 4, nr 131, s. 4, nr 133 dod. por., s. 3; Z żałobnej karty. Śp. Antoni Borzewski, „Tygodnik Ilustrowany”, 1920, nr 38, s. 735; A. Maciesza, Borzewski Antoni, w: Polski Stownik Biograficzny (dalej: PSB), t. 2, red. W. Konopczyński, Kraków 1936, s. 362; M. Krajewski, Borzewscy herbu Lubicz z Ugoszcza w Ziemi Dobrzyńskiej, Rypin 1990, s. 3-12; P. Gałkowski, Genealogia ziemiaństwa ziemi dobrzyńskiej XIX-XX wieku (do 1939 roku), Rypin 1997, s. 25-31.

8 Dobra w Ugoszczu zaliczane były w drugiej połowie XIX w. do rzędu dużych majątków, ale nie do największych znajdujących się na Ziemi Dobrzyńskiej. W pierwszej dekadzie następnego stulecia razem z Okoninem i Giżynkiem majątek liczył przeszło 1500 ha. P. Gałkowski, Genealogia..., dz. cyt., s. 29; M. Krajewski, Stulecie cukrowni Ostrowite 1900-2000, Rypin 2000, s. 7-8.

9 Ks. M. Smoleński przebywał od 22 lutego do 30 września 1866 r. w klasztorze w Oborach na przymusowym zesłaniu za udział w powstaniu styczniowym. Na podstawie zebranych w archiwum klasztornym materiałów opublikował dwie prace: najpierw artykuł w „Przeglądzie Katolickim”, który dotyczył dziejów klasztoru w Oborach, trzy lata później monografię poświęconą czterem kościołom na Ziemi Dobrzyńskiej. W obu tych pozycjach wzmiankował kaplicę Borzewskich w Oborach. Zob. M. Smoleński, Korespondencja „Przegladu Katolickiego”. Z diecezji płockiej, „Przegląd Katolicki”, 1866, nr 26, s. 411; M. Smoleński, Cztery kościoły w Ziemi Dobrzyńskiej, Lwów 1869, s. 44; M. Krajewski, Kościól i klasztor Ojców Karmelitów w Oborach, Obory 1986, s. 9.

10 KZSP, dz. cyt., s. 44.

11 Zob. M. Krajewski, Kościół..., dz. cyt., s. 21-23; M. Krajewski, A. Mietz, Zabytki..., dz. cyt., s. 102-105.

12 KZSP, dz. cyt., s. 44. Rodzicami, zmarłych w niemowlęctwie braci Zygmunta Rafała i Gustawa Adolfa byli Wawrzyniec hr. Benzelstjerna Engeström (1829-1910) i Jadwiga z Borzewskich (1831-1908), siostra rodzona Zdzisława Borzewskiego. Helena Michalina Borzewska (1845-1848) również była siostrą Zdzisława, córką Antoniego
} 
ścianie elewacji bocznej, z lewej strony, na której wyryto nazwiska zmarłych członków rodziny: Antoniego Borzewskiego (zm. 1860), Zdzisława Borzewskiego (zm. 1884), Stefana Borzewskiego (zm. 1904), Zdzisława Borzewskiego (zm. 1901), Antoniego Borzewskiego (zm. 1920), Julii z Piwnickich Borzewskiej (zm. 1893) i Marii z Szydłowskich Borzewskiej (zm. 1868), jak również metalową tabliczkę trumienną w kruchcie kaplicy dedykowaną Salomei z Nałęczów Borzewskiej (zm. 1833) ${ }^{13}$.

Dotychczasowi badacze, nie mogąc określić precyzyjnie formy architektonicznej kaplicy, definiowali jej styl jako eklektyczny ${ }^{14}$. Moim zdaniem połączono w nim elementy zaczerpnięte z renesansu włoskiego i romanizmu lombardzkiego. Źródeł kompozycji fasady należy szukać w architekturze włoskich kościołów średniowiecznych - skąd pochodzi pomysł płaskiej zwieńczonej trójkątnie fasady ozdobionej fryzem lombardzkim, ale również w fasadach świątyń renesansowych na terenie Italii, np. S. Andrea w Mantui Leona Battisty Albertiego (proj. 1472) - gdzie występuje jednoprzelotowy łuk triumfalny w formie głębokiej wnęki, umieszczony bezpośrednio pod niskim trójkątnym przyczółkiem i flankowany m.in. przez parę zakończonych półkoliście nisz przeznaczonych do ustawienia rzeźb. Zintegrowanie elementów o takim samym pochodzeniu regionalnym, lecz innym rodowodzie chronologicznym nastąpiło przed połową XIX w. w Niemczech, w środowisku berlińskich architektów - uczniów Karla Friedricha Schinkla (1781-1841) ${ }^{15}$.

Jednym z wychowanków znanego architekta był Friedrich August Stüler (1800-1865). Podobnie jak jego nauczyciel w swoich projektach próbował z powodzeniem łączyć „elementy tradycji antycznej i renesansowej z wzorami epok późniejszych"”16. W roku 1844 przygotował plany rozbudowy kościoła luterańskiego pw. św. Jana Chrzciciela (St. Johannis-Kirchhof) w dzielnicy Berlina - Moabit inspirowane architekturą romańską Lombardii i Emilia Romana oraz włoskiego Quattrocenta i Cinquecenta. Do pierwotnego kościoła zaprojektowanego przez Schinkla w stylu neoromańskim, który powstał w latach 1832-1835 ${ }^{17}$,

i Julii z Piwnickich. Zob. Archiwum Archidiecezjalne w Płocku (dalej: AAP), Akt urodzenia Heleny Michaliny Borzewskiej, par. Ruże, Ugoszcz, 1845, nr 100; AAP, Akt zgonu Heleny Michaliny Borzewskiej, par. Ruże, Ugoszcz, 1848, nr 64; APB, Akt małżeństwa Wawrzyńca Engeströma i Jadwigi Borzewskiej, par. Ruże, Ugoszcz, 1852, nr 7; Nekrolog Jadwigi z Borzewskich hr. Benzelstjerna-Engeström, „Kurier Warszawski”, 1908, nr 218, s. 6; Z. Grot, Engeström Wawrzyniec, w: PSB, t. 6, red. W. Konopczyński, Kraków 1948, s. 274-245; P. Gałkowski, Genealogia..., dz. cyt., s. 26.

13 Istnienie tablic odnotowuje dopiero w latach 80. XX w. Mieczysław Krajewski. Zob. M. Krajewski, Kościól..., dz. cyt., s. 22; M. Krajewski, A. Mietz, Zabytki..., dz. cyt., s. 104.

14 KZSP, dz. cyt., s. 44; M. Krajewski, A. Mietz, Zabytki..., dz. cyt., s. 104; Jedynie ks. M. Smoleński określił styl kaplicy jako gotycki. Zob. M. Smoleński, Cztery..., dz. cyt., s. 44.

15 Podstawową literaturę w tym temacie stanowi niemieckojęzyczna publikacja Evy Börsch-Supan i praca Marka Zgórniaka (I wyd. „Zeszyty Naukowe UJ. Prace z Historii Sztuki”, 1987, z. 18). Zob. E. Börsch-Supan, Berliner Baukunst nach Schinkel 1840-1870. Studien zur Kunst des 19.Jahrhunderts, Bd. 25, München 1977; M. Zgórniak, Wokól neorenesansu w architekturze XIX wieku. Podstawy teoretyczne i realizacje, Kraków 2013, s. 71-83.

16 Cyt. za: W. Baraniewski, T.S. Jaroszewski, Materiały do działalności architektonicznej Friedricha Augusta Stülera w Polsce, „Ikonotheka”, t. 11, 1996, s. 8.

17 Poświęcenie kościoła nastąpiło 24 czerwca 1835 r. St. Johannis-Kirchhof był jedną z czterech świątyń ewangelickich (inne to: Elisabethkirsche, St. Pauls von Tarsus Kirsche i Nazarethkirche), którą zbudowano na przedmieściach Berlina dla zaspokojenia religijnych potrzeb mieszkańców dynamicznie rozwijającego się miasta. Inicjatorem ich budowy był król pruski Fryderyk Wilhelm III. Przygotowane przez Schinkla plany zostały zatwierdzone w 1830 r. Budowa każdego z czterech kościołów trwała średnio dwa lata. Wszystkie ukończono i oddano do użytku wiernym w połowie 1835 r. Rok wcześniej zostały opublikowane w Buch Sammlung architektonische Entwürfe (Heft 22, Berlin 1834, Tafeln 159-160 i 161-162). Zob. W. Baraniewski, Projekty Karla Friedricha Schinkla dla Krzeszowic, „Kwartalnik Architektury i Urbanistyki”, 1982, z. 3-4, s. 255, ryc. 16, 17 i 19; M.A. Rusnak, Kultur 
zostały dołączone pomiędzy 1851 a 1856 r. trzy osobne budowle rozmieszczone po obu jego stronach: z lewej - dom parafialny i wysoka na 47, $60 \mathrm{~m}$ campanilla, z prawej - szkoła ${ }^{18}$. Nowo zbudowane obiekty Stüler połączył z kościołem krużgankami, te zaś skomunikował z prostokątną otwartą kruchtą dobudowaną przed portalem. Sposób połączenia świątyni za pomocą galerii arkadowych z budynkami, które są od niej odsunięte, powtarza rozwiązanie stosowane przez Andrea Palladia w podmiejskich założeniach willowych (tzw. układ palladiański $)^{19}$. Przypuszczalnie z architektury palladiańskiej pochodzi, występująca w fasadzie przedsionka, zamknięta łukiem pełnym arkada na kolumnach flankowana prostokątnymi wąskimi prześwitami ograniczonymi belkowaniem i filarami (tzw. motyw palladiański), nad którymi znajdują się pojedyncze tonda wypełnione płaskorzeźbioną rozetą. Motyw ten, będący modyfikacją rzymskiego trójprzelotowego łuku triumfalnego, stosowany był w Italii w XVI w. przez Sebastiana Serlia (tzw. serliana), Giulia Romano, Jacopa Sansovina czy Giorgia Vasariego. Jednakże projekt Palladia z 1549 r. obudowy ratusza w Vicenzy podwójną loggią (tzw. Basilica Palladiana) wydaje się być najbliższy realizacji architekta niemieckiego. Szczególnie jeśli weźmie się pod uwagę narożne przęsła w obu kondygnacjach budynku, w których występują bardzo wąskie przestrzenie wydzielone od strony arkady kolumnami, a od ściany pilastrami, i zaakcentowane powyżej belkowania okrągłym otworem. W dorobku architektonicznym Stülera motyw otwartej serliany pojawi się jeszcze co najmniej trzykrotnie. Po raz pierwszy w przyziemiu ryzalitu fasady Muzeum Narodowego w Sztokholmie (1848-1866), gdzie został powtórzony trzy razy. Następnie w pojedynczej formie w projekcie kruchy mauzoleum hrabiów Henckel von Donnersmarck, wzniesionego w latach 1858-1862 po śmierci Laury von Hardenberg (zm. 24 grudnia 1857, lat 45) przez jej męża Hugo na terenie założenia parkowo-zamkowego w austriackim Wolfsbergu (Karyntia), oraz w ryzalicie północno-wschodnim pałacu w Krzeszowicach pod Krakowem (1862-1865), będącego wówczas własnością hrabiego Adama Potockiego ${ }^{20}$. Z wyjątkiem gmachu muzeum, gdzie występuje porządek joński, w pozostałych wskazanych przykładach architekt zastosował porządek koryncki. Zbliżone do korynckich głowice wykorzystano w podporach serliany stanowiącej obramienie wejścia prowadzącego do przedsionka kaplicy Borzewskich na cmentarzu w Oborach. Tam również powtórzono pozostałe komponenty fasady zaprojektowanej przez Stülera kruchty do kościoła Johannis-Kirchhof w Berlinie.

\footnotetext{
Büro Elisabeth w Berlinie - kościoły do wynajęcia, „Budownictwo i Architektura”, 2017, nr 2, s. 66-67 (tam najnowsza literatura dotycząca kościołów podmiejskich autorstwa K.F. Schinkla).

18 Otwarcie kościoła nastąpiło 23 czerwca 1857 r. Zob. E. Börsch-Supan, D. Müller-Stüler, Friedrich August Stüler 1800-1865, Berlin 1997, s. 122-123, 525-527.

19 Motyw arkadowych krużganków połączonych tym razem z otwartym przyziemiem ryzalitu Stüler zastosował w fasadzie Uniwersytetu Albrechta w Królewcu, którego budowę rozpoczęto w 1844 r. Galerie, mimo iż wychodzą poza szerokość budynku, nie łączą go jednak z innymi obiektami.

20 W. Baraniewski, T.S. Jaroszewski, Materiały..., dz. cyt., s. 30-32. (tam literatura do pałacu w Krzeszowicach i mauzoleum w Wolfsbergu). W przypisie 24 autorzy artykułu zwracają uwagę, iż motyw otwartej serliany występował w twórczości Stülera częściej i był przedmiotem zainteresowania autorek artykułu Evy Börsch-Supan i Ursuli Harb poświęconego mauzoleum w Wolfsbergu (Mausoleum der Familie Henckel-Donnersmarck in Wolfsberg, „Österreichische Zeitschrift für Kunst und Denkmalpflege”, 40/1986, Heft 1-2, s. 28-43). Ponieważ nie udało mi się dotrzeć do wspomnianej publikacji, podstawowa wiedza na temat mauzoleum pochodzi z czasopisma „Atlas zur Zeitschrift für Bauwesen” (zob. Mausoleum für Gräfin Henkel zu Wolfsberg, „Atlas zur Zeitschrift für Bauwesen”, Jg. XI, 1861, Blatt 37-38), w którym opublikowano projekt Stülera. Wg pierwotnego zamysłu architekta fasada mauzoleum w Wolfsbergu miała mieć formę prostokątnej kruchty z otwartą serlianą, którą ostatecznie zastąpiono trójarkadowym portykiem.
} 
W kaplicy Borzewskich pominięto, co jest zrozumiałe, elementy wystroju rzeźbiarskiego związane z wezwaniem świątyni berlińskiej, tj. głowę Jana Chrzciciela w tondzie z parą aniołów po bokach trzymających w rękach krzyż i palmę męczeństwa ( $\rightarrow$ tympanon przyczółka) oraz posągi czterech Ewangelistów ( $\rightarrow$ nisze w lizenach narożnych). Zapewne w niszach fasady kaplicy grobowej planowano wstawić jakieś rzeźby. Nie wiadomo jednak jakie, ponieważ nie udało się odnaleźć przekazów pisemnych bądź ikonograficznych, które pozwoliłyby na taką identyfikację. Być może - co należy oczywiście wziąć pod uwagę - nie planowano ich w ogóle. Ich liczba została zredukowana z dwóch par do jednej. Zamiast nisz w dolnej kondygnacji fasady wprowadzono prostokątne pionowe płyciny z kolistą wnęką pośrodku, które razem z czworobocznymi płycinami pod niszami górnej kondygnacji i trójkątnymi w pachach arkady (w Oborach bez rozet w tondach) tworzą linearną siatkę podziałów o proweniencji renesansowej, ale w interpretacji dziewiętnastowieczneje ${ }^{21}$.

Dobry poziom artystyczny kaplicy Borzewskich skłania, aby w tym samym środowisku architektonicznym, z którego pochodził wzór fasady, szukać inspiracji dla obramień okien umieszczonych pośrodku elewacji bocznych. Oprawę pojedynczego otworu okiennego w kaplicy w Oborach stanowi trójarkadowy portyk o pełnych łukach wsparty na kolumnach korynckich i filarach toskańskich, umieszczony w prostokątnym pseudoryzalicie. Podziały ramowe uzupełniają trójkątne płyciny w pachach arkad, gzyms wieńczący występ i wypełnienie podokiennika $\mathrm{w}$ formie prostokątnej ramy z umieszczoną w niej czworoboczną płytą ze sfazowanymi krawędziami. Wymienione detale należą zarówno do repertuaru włoskiej architektury romańskiej ( $\rightarrow$ typ okna lub przezrocza podzielonego na trzy części za pomocą pary kolumienek), jak i renesansowej ( $\rightarrow$ trójarkadowa loggia). Ten rodzaj dekoracji w powiązaniu z klasycystyczną strukturą stał się bardzo modny w Europie, szczególnie w Niemczech, gdzie już na początku XIX w. zaznaczył się w obiektach projektowanych w stylu neorenesansowej willi toskańskiej oraz w postaci tzw. Rundbogenstil, czyli stylu arkadowego wzbogaconego o elementy architektury wczesnochrześcijańskiej, romańskiej i bizantyjskiej. Dalszą jego kontynuację stanowił neorenesans w interpretacji architektów pruskich i bawarskich (tzw. Maximilianstil) ${ }^{22}$, których działalność przypadła na połowę XIX stulecia. Głównym ośrodkiem popularyzującym neorenesansowe formy w architekturze Europy Środkowo-Wschodniej był Berlin. Za przykład mogą posłużyć projekty budynków mieszkalnych przeznaczone do zabudowy ulicy Victoriastraße, głównej arterii w dzielnicy Berlina - Remperhoff, przed Bramą Poczdamską. Ich budowa miała miejsce w latach 18551859, po rozpoczęciu sprzedaży działek w 1855 r. Jednym z projektantów był architekt Georg Friedrich Heinrich Hitzig (1811-1881), który praktykę budowlaną rozpoczynał u Schinkla ${ }^{23}$.

\footnotetext{
21 Opisane formy rozczłonkowujące lico ściany Stüler chętnie stosował w innych projektach. Np. wertykalne prostokątne płyciny z centralnie umieszczoną okrągłą wnęką pojawiają się w ryzalicie Muzeum Narodowego w Sztokholmie (1848-1866) i w pałacu w Dąbrówce Wielkopolskiej (woj. lubuskie; 1856-1859).

22 Charakterystykę stylu maksymiliańskiego najpełniej przedstawił w literaturze polskiej Tomasz Grygiel. Zob. T. Grygiel, Dom Lesserów w Warszawie - nieznane dzieło „, stylu maksymiliańskiego”, w: Architektura XIX i początku XX wieku, red. T. Grygiel, Wrocław-Warszawa-Kraków 1991, s. 48-52 (tam literatura, przypis 1).

${ }^{23}$ Obok Hitziga domy przy ul. Wiktorii w Berlinie projektował w tym czasie Martin Gropius. Zob. Wohnhäuser in der Victoria-Straße zu Berlin. Nach photographischen Ausnahmen (Tafel 34 und 35), ,Zeitschrift für praktische Baukunst", Bd. 23, 1863, szp. 289-290; F. Hitzig, Wohngebäude der Victoria Straße in Berlin, Berlin 1864 (zbiór projektów domów mieszkalnych, poprzedzony wprowadzeniem i uzupełniony planem z zaznaczeniem działek i domów); A. Körte, Martin Gropius. Leben und Werk eines Berliner Architekten (1824-1880), Berlin 2013, s. 100-113 .
} 
W Polsce znany jest jako twórca pałacu Leopolda Kronenberga w Warszawie (1868-1871; niezachowany) ${ }^{24}$. Wśród serii planów domów przygotowanych przez niego do zabudowy Victoriastraße, jeden z budynków oznaczony nr 6 posiada obramienie głównego wejścia, które bardzo przypomina rozwiązanie zastosowane w elewacjach bocznych kaplicy w Oborach. W projekcie Hitziga drzwi wejściowe razem z parą okien zostały wkomponowane w prostokątny pseudoryzalit z trójarkadowym portykiem przyściennym o zróżnicowanych w przekroju podporach z kapitelami korynckimi, w układzie A-B-B-A, gdzie „A " - to filar, a „B” - to kolumna. Wszystkie otwory i łuki arkad otrzymały zamknięcia półkoliste ${ }^{25}$. W tym samym projekcie pojawia się jeszcze inny motyw widoczny na fasadzie kaplicy Borzewskich. Są to wąskie, pionowe płyciny z okrągłą wnęką w połowie wysokości dłuższego boku, umieszone pomiędzy parami prostokątnych okien. Wspólne dla obu realizacji są też otynkowane elewacje i detal architektoniczny, który został utrzymany w takiej samej kolorystyce co ściany. Graficzna niemal płaska elewacja stanowiła przeciwieństwo fasady stülerowskiej kruchty z krużgankami, którą wzniesiono z czerwonej cegły i skontrastowano dla osiągnięcia plastycznego efektu z jasnym piaskowcem użytym do wykonania kolumn. Przy sporządzaniu projektu dla Zdzisława Borzewskiego przez nieznanego z imienia i nazwiska architekta zwyciężyło rozwiązanie zastosowane w projekcie domu przy Victoriastraße 6, czyli utrzymanie otynkowanych ścian ceglanych i detalu architektonicznego w tym samym kolorze.

Szukając odpowiedzi na pytanie, kim był projektant kaplicy grobowej dziedziców z Ugoszcza, należy najpierw rozważyć, czy mógł być to jeden z wymienionych architektów berlińskich. Ks. Maciej Zagłoba Smoleński, który pierwszy odnotowuje fakt powstania kaplicy na cmentarzu w Oborach, przemilcza tę istotną z punktu widzenia historyka informację. Późniejsze opracowania także nie podają nazwiska projektanta. Z kolei popularność tych dwóch architektów, szczególnie Stülera wśród polskich zleceniodawców dowodzi, że chętnie korzystano z ich usług. Klientami Stülera byli bogaci ziemianie: Aleksander Gonzaga Myszkowski hr. Wielopolski (przebudowa Zamku na Mirowie w Książu Wielkim, 1841-1845), hrabia Józef Mycielski (pałacyk-willa w Kobylem Polu k. Poznania, 1842-1844 i zamek w Rokosowie, 1849-1854), hrabia Władysława Emeryk Leszczyc-Radoliński (pałac w Jarocinie, 1845-1855), hrabia Adam Potocki (pałac i kaplica cmentarna w Krzeszowicach, 1862-1865), książę Ireneusz Kleofas Ogiński (pałac i kościół św. Michała w Retowie na Żmudzi, 1853-1874) czy Stefan Narzymski h. Dołęga (zamek i kościół św. Wojciecha w Jabłonowie Pomorskim, 1854-1866) ${ }^{26}$. Na terenie Kujaw podług planów Stülera zostały zrealizowane w stylu neorenesansowym pałac w Wierzbiczanach (pow. inowrocławski) dla braci Ryszarda i Hermana von Roy (1845-1846, niezachowany) oraz kościół pw. św. Mateusza w Gębicach (pow. mogileński; 1862-1874), który przebudowano w stylu neogotyckim ${ }^{27}$. Projekt kaplicy mieści się więc w przedziale czasowym, w którym Stüler był czynny zawodowo,

\footnotetext{
24 T.S. Jaroszewski, Dzieje pałacu Kronenberga, Warszawa 1972; T.S. Jaroszewski, Pałac warszawskiego bankiera doby pozytywizmu, w: Sztuka 2 połowy XIX wieku. Materiały Sesji Stowarzyszenia Historyków Sztuki, Łódź, listopad 1971, red. T. Hrankowska, Warszawa 1973, s. 79-100.

${ }_{25}$ Projekt domu przy Victoriastraße 6 w Berlinie był publikowany w berlińskim czasopiśmie „Zeitschrift für praktische Baukunst", Bd. 23, 1863, Tafel 35.

26 W. Baraniewski, T.S. Jaroszewski, Materiały ..., dz. cyt., s. 7-48.

27 M. Pawłowska, Pałac $w$ Wierzbiczanach. Neorenesansowe założenie pałacowo-parkowe na Kujawach, „Materiały do Dziejów Kultury i Sztuki Bydgoszczy i Regionu", 2006, z. 11, s. 83-88.
} 
a wieś Obory znajduje się w pobliżu dwóch innych miejscowości na Kujawach, w których zrealizowano jego projekty. W twórczości Stülera można ponadto odnaleźć zbliżone do oborskich obramienia trójdzielnych okien. Występują one w neorenesansowych fasadach Uniwersytetu Albrechta (tzw. Albertiny) w Królewcu (1844-1863) i w pałacu w Dąbrówce Wielkopolskiej (1856-1859). Ich wysmuklone proporcje i sposób rozmieszczenia na elewacji odbiegają jednak od realizacji nowożytnych, kojarząc się raczej z budowlami późnego gotyku w Anglii niż z włoskim renesansem.

Połączenie dwóch tak różnych wydawałoby się cytatów architektonicznych: kruchty kościoła św. Jana Chrzciciela i oprawy architektonicznej wejścia do domu przy ulicy Victoriastraße 6, które poza miejscem (obie budowle powstały w Berlinie), łączy jeszcze taki sam czas budowy - druga połowa lat 50. XIX w. i kostium historyczny - neorenesans o włoskiej genezie, było możliwe dzięki popularnym w tym czasie wydawnictwom i prasie ilustrowanej. Projekt Stülera został opublikowany w 1861 r. w „Architektonisches Skizzenbuch” ${ }^{28}$, plany Hitziga zamieścił dwa lata później „Zeitschrift für praktische Baukunst”29. Jest mało prawdopodobne, aby któryś z wymienionych architektów był projektantem kaplicy w Oborach. Bardziej realne jest, że twórcą budowli grobowej był mniej sławny architekt, który jednak dobrze znał ówczesne realizacje architektury szkoły berlińskiej albo z autopsji, albo - ku czemu bardziej się skłaniam - w swojej bibliotece posiadał oba czasopisma. Wykorzystanie pochodzących stamtąa projektów tłumaczyłoby niemal dosłowne powtórzenie form architektonicznych, które w innym przypadku może by nigdy nie wystąpiły obok siebie w jednej realizacji ${ }^{30}$.

\footnotetext{
28 Vorhalle der Kirche zu Moabit bei Berliner, „Architektonisches Skizzenbuch”, 1861, Heft XLIX, Blatt 4.

${ }^{29}$ „Zeitschrift für praktische Baukunst”, Bd. 23, 1863, Tafel 35. Projekt był również reprodukowany w 1864 r. w albumie autorskim Hitziga. Zob. F. Hitzig, Wohngebäude..., dz. cyt., Bl. VII i XI.

${ }^{30}$ Możliwe, że był nim ten sam architekt, którego Borzewscy zatrudnili do przebudowy pałacu. Neorenesansowy pałac w Ugoszczu powstał w wyniku rozbudowy dworu z końca XVIII w. Nieznana jest dokładna data jego budowy, ani osoba, której inicjatywie zawdzięczał swoje powstanie. Badacze dziejów pałacu wskazują Julię z Piwnickich Borzewską (1807-1893), wdowę po Antonim Borzewskim (z archiwalnych dokumentów z 1863 r. wynika, że syn był winny matce $44937 \mathrm{rs}$. za ,wzniesienie nowych budowli murowanych w dobrach jego dziedzicznych Ugoszczu i Okoninie”), albo jej syna, Zdzisława (od 1858 r. właściciela majątku). Czas budowy pałacu określa się, uwzględniając formę architektoniczną, na lata 60. lub 70. XIX w. Zob. P. Gałkowski, Genealogia ..., dz. cyt., s. 28; R. Hankowska, Ugoszcz..., dz. cyt., s. 175-178.
} 


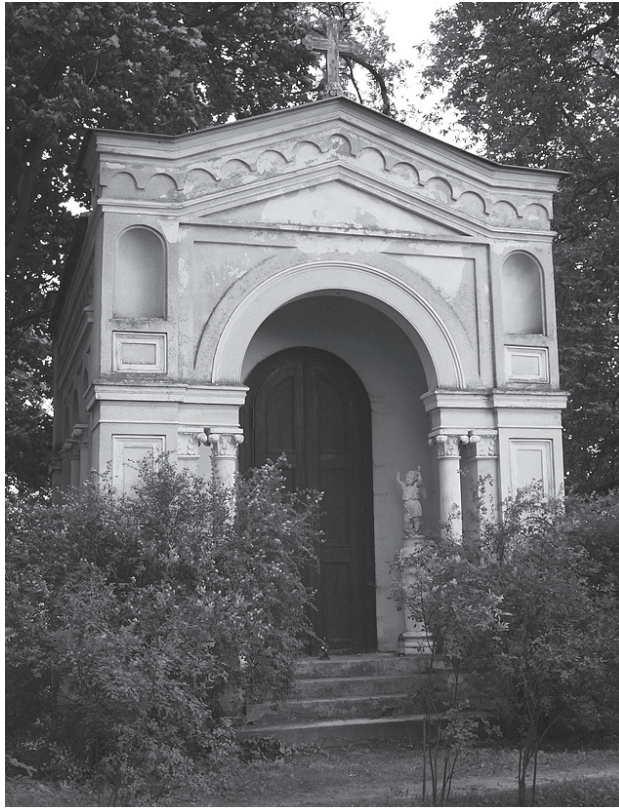

1. Kaplica Borzewskich na cmentarzu w Oborach - fasada. Fot. D. Kawka

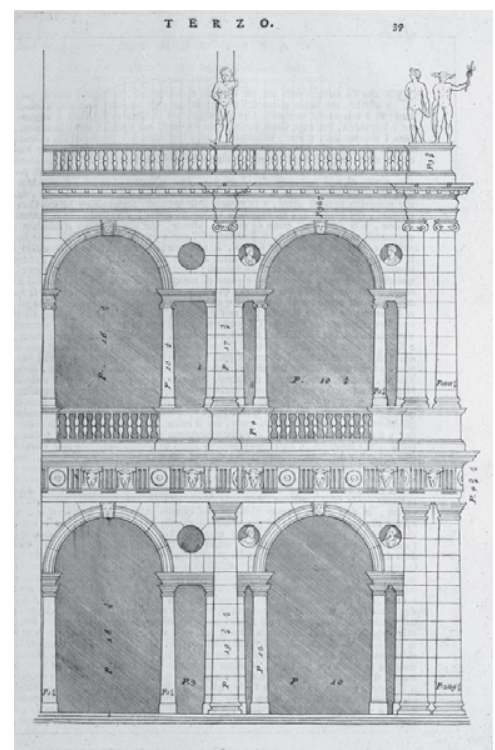

3. Ratusz w Vicenzy - proj. A. Palladio. Repr. z I Quattro Libri dell'Architecttura, Venice 1771, s. 39

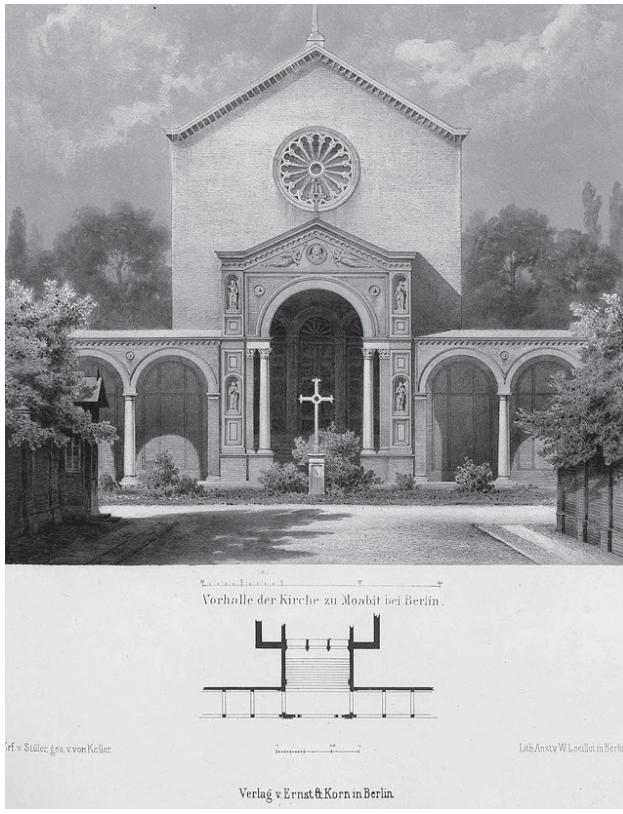

2. Kruchta i krużganki przed kościołem św. Jana Chrzciciela w Berlinie - proj. F.A. Stüler. Repr. z „Architektonisches Skizzenbuch”, 1861, Heft XLIX, Blatt 4

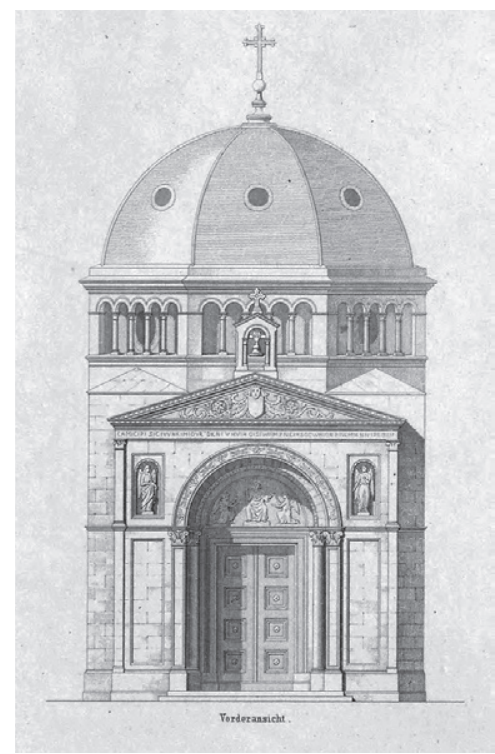

4. Mauzoleum hr. Henckel von Donnersmarck - proj. F.A. Stüler. Repr. z „Atlas zur Zeitschrift für Bauwesen”, Jg. XI, 1861, Blatt 37 


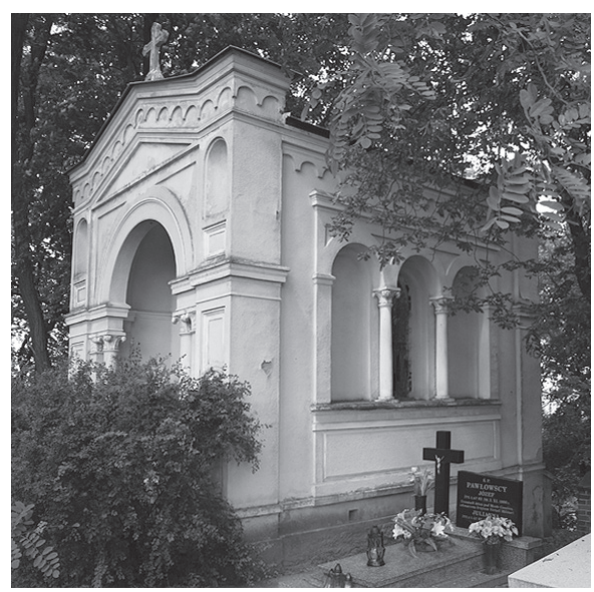

5. Kaplica Borzewskich na cmentarzu w Oborach - elewacja boczna. Fot. D. Kawka

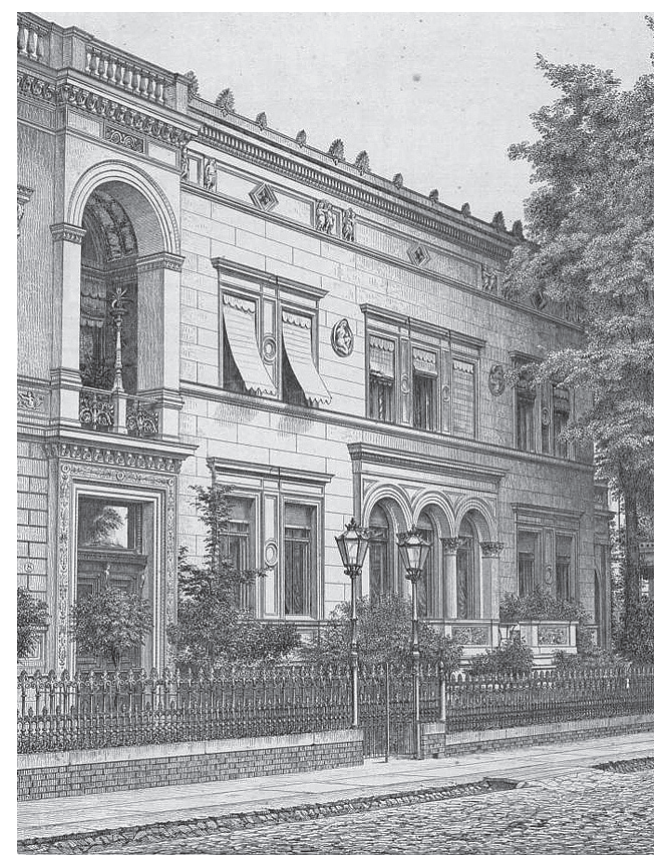

6. Dom przy Victoriastraße 6 w Berlinie - proj. G.F. Hitzig. Repr. z ,Zeitschrift für praktische Baukunst", Bd. 23, 1863, Tafel 35

\section{Bibliografia}

AAP, Akt zgonu Heleny Michaliny Borzewskiej, par. Ruże, Ugoszcz, 1848, nr 64.

APB, Akt zgonu Antoniego Borzewskiego, par. Ruże, Ugoszcz, 1860, nr 31.

APT oddz. we Włocławku, Akt ślubu Ludwika Borzewskiego i Salomei Nałęcz, par. Kikół, 1796 (2 II 1796).

APT oddz. we Włocławku, Akt urodzenia Zdzisława Gabriela Ludwika Stanisława Zygmunta Borzewskiego, par. Ruże, 1833, nr 44.

APT oddz. we Włocławku, Akt Zgonu Salomei z Nałęczów Borzewskiej, par. Ruże, Gizinek, 1833, nr 18.

Archiwum Archidiecezjalne w Płocku (dalej: AAP), Akt urodzenia Heleny Michaliny Borzewskiej, par. Ruże, Ugoszcz, 1845, nr 100.

Archiwum Archidiecezjalne we Włocławku, Akt urodzenia Antoniego Grzegorza Feliksa Borzewskiego, par. Czernikowo, 1796, nr 3972.

Archiwum Państwowe w Bydgoszczy (dalej: APB), Akt matżeństwa Wawrzyńca Engeströma i Jadwigi Borzewskiej, par. Ruże, Ugoszcz, 1852, nr 7.

Archiwum Państwowe w Toruniu oddział we Włocławku (dalej: APT oddz. we Włocławku), Akt urodzenia Ludwika Borzewskiego, par. Kikół, 1758 (17 X 1858). 
Baraniewski W., Jaroszewski T.S., Materiały do działalności architektonicznej Friedricha Augusta Stülera w Polsce, „Ikonotheka”, t. 11, 1996, s. 7-48.

Baraniewski W., Projekty Karla Friedricha Schinkla dla Krzeszowic, „Kwartalnik Architektury i Urbanistyki”, 1982, z. 3-4, s. 241-259.

Börsch-Supan E., Berliner Baukunst nach Schinkel 1840-1870. Studien zur Kunst des 19. Jahrhunderts, Bd. 25, München 1977.

Börsch-Supan E., Müller-Stüler D., Friedrich August Stüler 1800-1865, Berlin 1997.

Gałkowski P., Genealogia ziemiaństwa ziemi dobrzyńskiej XIX-XX wieku (do 1939 roku), Rypin 1997.

Grot Z., Engeström Wawrzyniec, w: Polski Słownik Biograficzny, t. 6, red. W. Konopczyński, Kraków 1948, s. 274-245.

Grygiel T., Dom Lesserów w Warszawie - nieznane dzieło „stylu maksymiliańskiego”, w: Architektura XIX i początku XX wieku, red. T. Grygiel, Wrocław-Warszawa-Kraków 1991, s. 39-53.

Hankowska R., Ugoszcz - pałac, w: Materiały do dziejów rezydencji w Polsce. Ziemia Dobrzyńska, t. 2, cz. 1, red. S. Kunikowski, Włocławek 2002, s. 161-190.

Hitzig F., Wohngebäude der Victoria Straße in Berlin, Berlin 1864.

Jaroszewski T.S., Dzieje pałacu Kronenberga, Warszawa 1972.

Jaroszewski T.S., Pałac warszawskiego bankiera doby pozytywizmu, w: Sztuka 2 połowy XIX wieku. Materiały Sesji Stowarzyszenia Historyków Sztuki, Łódź, listopad 1971, red. T. Hrankowska, Warszawa 1973, s. 79-100.

Katalog Zabytków Sztuki w Polsce, t. 11: Woj. bydgoskie, z. 9 pow. lipnowski, opr. R. Brykowski, I. Galicka, H. Sygietyńska, Warszawa 1969.

K.J., (Art. nad.) Z Lipnowskiego dn. 15go lipca, „,Kurier Warszawski”, 1860, nr 220, s. 1246.

Körte A., Martin Gropius. Leben und Werk eines Berliner Architekten (1824-1880), Berlin 2013.

Krajewski M., Borzewscy herbu Lubicz z Ugoszcza w Ziemi Dobrzyńskiej, Rypin 1990.

Krajewski M., Kościół i klasztor Ojców Karmelitów w Oborach, Obory 1986.

Krajewski M., Mietz A., Zabytki ziemi dobrzyńskiej. Przewodnik biograficzny, Włocławek 1996.

Krajewski M., Stulecie cukrowni Ostrowite 1900-2000, Rypin 2000.

Maciesza A., Borzewski Antoni, w: Polski Słownik Biograficzny, t. 2, red. W. Konopczyński, Kraków 1936, s. 362.

Mausoleum für Gräfin Henkel zu Wolfsberg, „Atlas zur Zeitschrift für Bauwesen”, Jg. XI, 1861, Blatt 37-38.

Nekrolog Jadwigi z Borzewskich hr. Benzelstjerna-Engeström, „Kurier Warszawski”, 1908, nr 218, s. 6.

Nekrolog Marii z Szydłowskich Borzewskiej, „Dziennik Poznański”, 1868, nr 199, b.s. (z dn. 30 VIII).

Nekrolog Zdzisława Borzewskiego (syna Zdzisława i Zofii z Kożuchowskich), „Kurier Warszawski”, 1901, nr 130, s. 4, nr 131, s. 4, nr 133 dod. por., s. 3.

Nekrolog Zdzisława Borzewskiego, „Kurier Warszawski”, 1884, nr 189a, s. 3, nr 191a, s. 1.

Pawłowska M., Pałac w Wierzbiczanach. Neorenesansowe założenie pałacowo-parkowe na Kujawach, „Materiały do Dziejów Kultury i Sztuki Bydgoszczy i Regionu”, 2006, z. 11, s. $83-88$. 
Rusnak M.A., Kultur Büro Elisabeth w Berlinie - kościoły do wynajęcia, „Budownictwo i Architektura", 2017, nr 2, s. 65-80.

Smoleński M., Cztery kościoły w Ziemi Dobrzyńskiej, Lwów 1869.

Smoleński M., Korespondencja „Przeglądu Katolickiego”. Z diecezji płockiej, „Przegląd Katolicki", 1866, nr 26, s. 409-413.

Vorhalle der Kirche zu Moabit bei Berliner, „Architektonisches Skizzenbuch”, 1861, Heft XLIX, Blatt 4.

Wohnhäuser in der Victoria-Straße zu Berlin. Nach photographischen Ausnahmen (Tafel 34 und 35), „Zeitschrift für praktische Baukunst”, Bd. 23, 1863, szp. 289-290, Tafel 35.

Z żałobnej karty. Śp. Antoni Borzewski, „Tygodnik Ilustrowany”, 1920, nr 38, s. 735.

Zgórniak M., Wokół neorenesansu w architekturze XIX wieku. Podstawy teoretyczne i realizacje, Kraków 2013. 